\title{
Archivos de Zootecnia. Editorial Report 2016
}

\begin{abstract}
Navas González, F.J. ' ; Nogales Baena, S. '; Arando Arbulu, A. ${ }^{\text {; }}$ Delgado Bermejo, J. V. ' ; López de Bustamante, M.C. ${ }^{1}$ and
\end{abstract} Gómez Castro, A.G.'

'Editorial Office of Archivos de Zootecnia. Animal Production Department. Faculty of Veterinary Sciences. University of Córdoba. Rabanales University Campus. Córdoba. Spain.

${ }^{2}$ Genetics Department. Faculty of Veterinary Sciences. University of Córdoba. Rabanales University Campus. Córdoba. Spain.

\section{ADDITIONAL KEYWORDS}

Scientific journals.

Scientific manuscripts.

Editorial activity.

Zootechnics.

Animal Production.

\section{SUMMARY}

Archivos de Zootecnia reached its 252 issue during 2016. In the present editorial report, we address the facts and figures derived from the editorial process during the past yearly editorial cycle. The updates carried out on the journal mainly head towards the successful implementation of the Open Journal System on its new website (https://www.uco.es/ucopress/az/index.php/ az) from September 2016, and the changes in the Editorial Office aim at enhancing the scientific relevance of the journal through the use of new channels available which may enable a greater distribution among the scientific community. A total of 362 manuscripts coming from 21 countries. Although Brazil was still the most contributing country the percentage of submissions slightly decreased $(69.45 \%)$ in favour of an increase of the submissions by authors from other countries. Therefore, the most frequently used language in the manuscripts was Portuguese, followed by Spanish, English and French. 93 works were published in 2016: 57 articles, 26 short notes and 10 reviews. Published papers came from 16 countries. The two main topics the articles were about were Feeding and food ( $n=27 ; 29.03 \%)$ and Breeding and genetics $(n=20 ; 21.50 \%)$; while the most frequent species the works dealt with was cattle $(n=77 ; 21.27 \%)$ followed by sheep $(n=62 ; 17.12 \%)$. Editorial times between the reception and publication of the manuscripts have comparatively improved according to the results showed in previous years' reports.

\section{Archivos de Zootecnia. Informe Editorial 2016}

\section{RESUMEN}

\section{PaLABRAS CLAVE ADICIONALES}

Revistas cientíicas.

Trabajos científicos.

Actividad editorial.

Zootecnia.

Producción Animal

\section{INFORMATION}

Cronología del artículo.

Recibido/Received: 15.04.2017

Aceptado/Accepted: 15.04.2017

On-line: 15.04 .2017

Correspondencia a los autores/Contact e-mail:

archivoszootecnia@uco.es

\section{INTRODUCTION}

Last year's report highlighted the remarkable need to work and focus on the reduction of the editorial times of Archivos de Zootecnia. Furthermore, it addressed the measures to be taken on order to update of the system used to process the manuscript received and the changes occurring in the Editorial Board, which started being implemented in the last trimester of 2016. The consolidation of such changes started in 2015 has been formalized. To this aimthe journal agreed to change the regular publication date so that the issues are published at the beginning of each subperiod (from the $15^{\text {th }}$ day to the $15^{\text {th }}$ day, each three months). Numbers are regularly published each year in January, April, July and October. On the other hand, the editorial board would like to acknowledge the role of language editorial reviewers, which have been in charge of the revision of the manuscripts before their publication, bolstering the best possible use of the different languages the works may be published in, and which are allowed to be used by the editorial board of the journal, providing the documents 


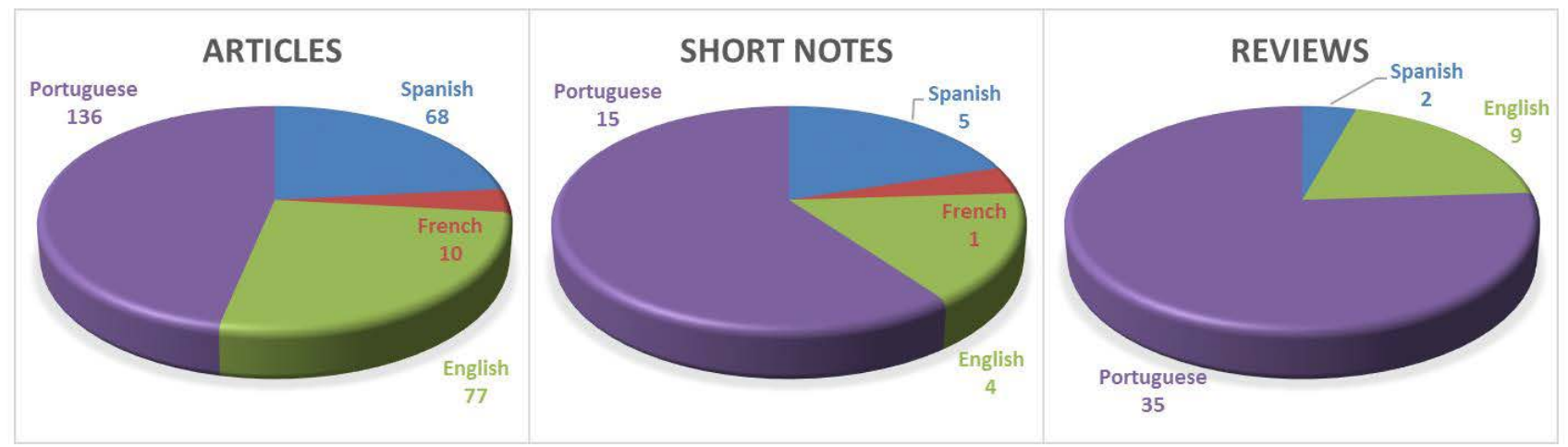

Figure 1. Language used in the manuscripts received during 2016 (Lenguaje empleado en los manuscritos recibidos durante 2016).

with a greater language quality. The Open Journal Systems (OJS) has been implemented satisfactorily and 88 manuscripts were received since the platform was open to the authors. Several improvements have been performed over the materials appearing in the website in order to make the submission and review process easier what may result in shortening the time needed for the manuscripts to be accepted and published. However, the implementation of the new system has slightly increased editorial times, therefore current actions focusing on training the people in the Editorial Board to recover last years' decreasing trend are being put into practice as well.

\section{SUBMISSIONS}

A total of 362 manuscripts (Figures $\mathbf{1}$ and 2, and Table II) were received, namely, 291 were classified as articles, 25 as short communications and 46 were reviews.

Table I. Origin (\%) of the authors of manuscripts received and published during 2016 (Origen (\%) de los autores de los manuscritos recibidos y publicados durante 2016).

\begin{tabular}{|c|c|c|c|c|c|c|c|c|}
\hline Country & $\mathrm{Ar}$ & $\mathrm{Nr}$ & $\mathrm{Rr}$ & $\operatorname{Pr}$ & Ap & $\mathrm{Np}$ & $\mathrm{Rp}$ & $\mathrm{Pp}$ \\
\hline Argelia & 2.22 & 2.7 & - & 2.0 & - & 2.8 & - & 0.8 \\
\hline Argentina & 1.65 & - & 1.1 & 1.5 & 7.4 & 2.1 & - & 5.2 \\
\hline Benin & 1.08 & 0.7 & - & 0.9 & - & - & - & - \\
\hline Brasil & 65.45 & 75.7 & 95.5 & 69.5 & 52.9 & 30.3 & $10-$ & 50.2 \\
\hline Canada & -7 & - & - & 0.1 & - & - & - & - \\
\hline Chile & 0.79 & - & - & 0.6 & - & 6.2 & - & 1.9 \\
\hline Colombia & 7.74 & 2.7 & - & 6.5 & 4.0 & - & - & 2.5 \\
\hline Cuba & 0.72 & 6.8 & 1.1 & 1.3 & - & 2.8 & - & 0.8 \\
\hline Ecuador & 0.79 & - & - & 0.6 & 0.7 & 7.6 & - & 2.7 \\
\hline Eslovaquia & -0 & - & 0.6 & 0.1 & - & - & - & - \\
\hline España & 3.87 & - & - & 3.1 & 19.5 & 38.6 & - & 23.6 \\
\hline Guatemala & 0.36 & 2.7 & - & 0.5 & - & - & - & - \\
\hline Hungria & - & - & - & - & 0.3 & - & - & 0.2 \\
\hline Iran & 0.36 & - & - & 0.3 & - & - & - & - \\
\hline Mexico & 3.30 & 5.4 & - & 3.1 & 6.4 & 6.2 & - & 5.8 \\
\hline Nigeria & 8.89 & 3.4 & 0.6 & 7.5 & 5.4 & - & - & 3.3 \\
\hline Paquistan & 0.22 & - & 1.1 & 0.3 & - & - & - & - \\
\hline Peru & 0.50 & - & - & 0.4 & - & - & - & - \\
\hline Portugal & - & - & - & - & 3.0 & 0.7 & - & 2.1 \\
\hline Siria & 0.14 & - & - & 0.1 & - & - & - & - \\
\hline Syria & 0.22 & - & - & 0.2 & - & - & - & - \\
\hline Uruguay & 0.57 & - & - & 0.5 & - & 0.7 & - & 0.2 \\
\hline Usa & - & - & - & - & - & 0.7 & - & 0.2 \\
\hline Venezuela & 1.08 & - & - & 0.9 & 0.3 & 0.7 & - & 0.4 \\
\hline
\end{tabular}


Table II. Topics dealt with in manuscripts received and published during 2016 (Temas tratados en los manuscritos recibidos y publicados durante 2016).

\begin{tabular}{|c|c|c|c|c|}
\hline & Articles & Short notes & Reviews & Papers \\
\hline Animal behavior and welfare & 3 & 1 & 2 & 6 \\
\hline Breeding and genetic & 11 & 9 & - & 20 \\
\hline Economy and management & 7 & 4 & - & 11 \\
\hline Environment & - & 1 & - & 1 \\
\hline Farming systems & - & 1 & - & 1 \\
\hline Feeding and foods & 16 & 4 & 7 & 27 \\
\hline Growth & 1 & 1 & - & 2 \\
\hline Health & 5 & 1 & 1 & 7 \\
\hline Production techniques & 5 & - & - & 5 \\
\hline Reproduction & 3 & - & - & 3 \\
\hline Products & 6 & 4 & - & 10 \\
\hline Total & 57 & 26 & 10 & 93 \\
\hline
\end{tabular}

The quantity of manuscripts submitted as original articles, short communications and reviews has increased contrasting the results from the previous year (Nogales Baena et al., 2016) and is still continuously increasing. The manuscripts were received in four different languages, e.g., Portuguese, Spanish, English and French in decreasing order of respective frequency importance, even though acceptance rates were not currently equivalent for all languages not even for their authors countries. Portuguese was used in the $51.38 \%$ of the documents, followed by English in a $24.86 \%$ of the cases. Comparing this fact to the origin of the authors, the results showed most of them were from countries where Portuguese is the official language. Spanish was present in a $20.72 \%$ of the cases. This results contrast the figures from 2014 (Nogales Baena et al., 2015), when the Spanish language reached the second position pushing English to the third position and compares the trends described in past year report (Nogales Baena et al., 2016). The journal continues to make efforts so as to help improve papers proceeding from low-income in which cultural and organizational difficulties may exist, with high scientific quality, allowing them to reach a standard that is more consistent, therefore matching the standards requested by the scientific nowadays. Submitted manuscripts have been classified according to their original language in Figure 1.

When assessing the author's origin, Brazilians were the most frequent senders, and their number slightly decreased again when compared to the results showed by the two previous report (Nogales Baena et al., 2015; 2016) as a consequence of the increase in the number of manuscript submitted from other countries. The authors' origin of the rest of the papers was unequally shared among the 20 countries related in Table

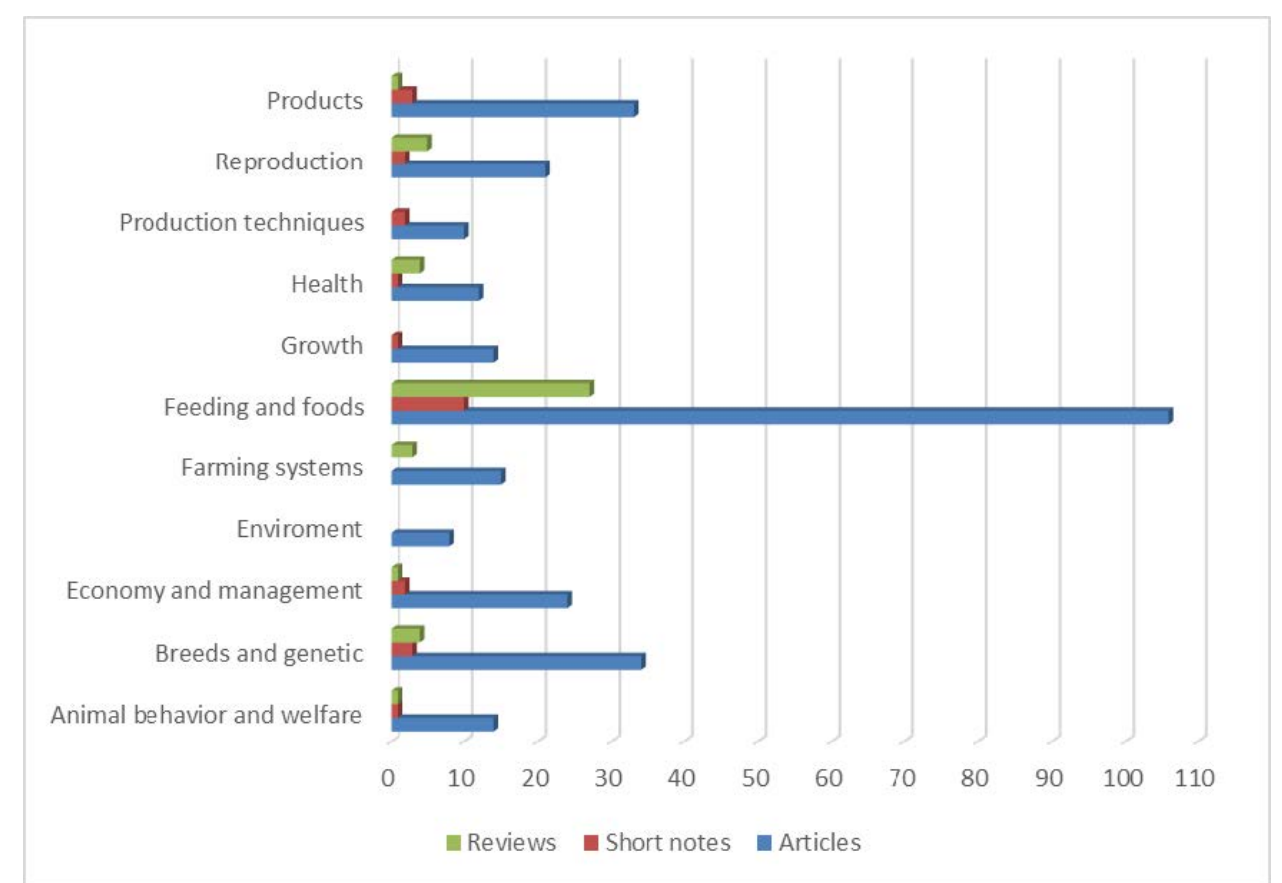

Figure 2. Topics covered in manuscripts received and published during 2016 (Temas tratados en los manuscritos recibidos y publicados durante 2016). 
I. Apart from Brazil a greater number of countries was able to reach a close to $5 \%$ submission, therefore highlighting the increasing proceeding heterogeneity, which may be very interesting for the journal, as may be able to supply valuable information for different worldwide contexts.

Figure 2 presents the number of manuscripts sorted by the topics with which they dealt. Regarding received manuscripts, 143 out of the total of 362 manuscripts received were about Feeding and Food with a much higher percentage than the rest of the topics issued. The second and third most frequent topics were Breeding and Genetics (41/362) and Products (37/362), whose percentages have inversely changed in order, when comparing them to the results obtained in 2014 and 2015.

\section{PUBLISHED DOCUMENTS}

In 2016, a total of 93 research documents were published accounting for a total of 596 edited pages as shown in Figures 3 and 4. The documents published were, namely 57 papers, 26 short communications and 10 reviews. This translates into an increase of $23.6 \%$ in the papers published, and of almost a $19.6 \%$ in the number of pages, which contrasts the results obtained in 2014 and compares to those from 2015. When thoroughly assessing the details of the obtained data, it can be ensured that the number of articles, short notes and especially reviews, which are eventually publis-

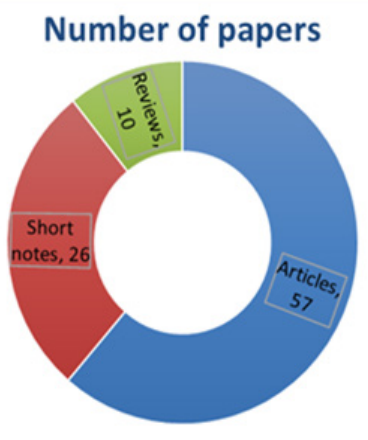

articles $\mathbf{n}$ Short notes $=$ Reviews

Figure 3. Manuscripts published in 2016 (Manuscritos publicados durante 2016).

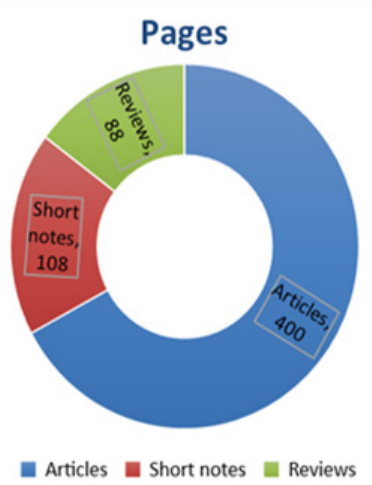

Figure 4. Pages published in 2016 (páginas publicadas durante 2016).

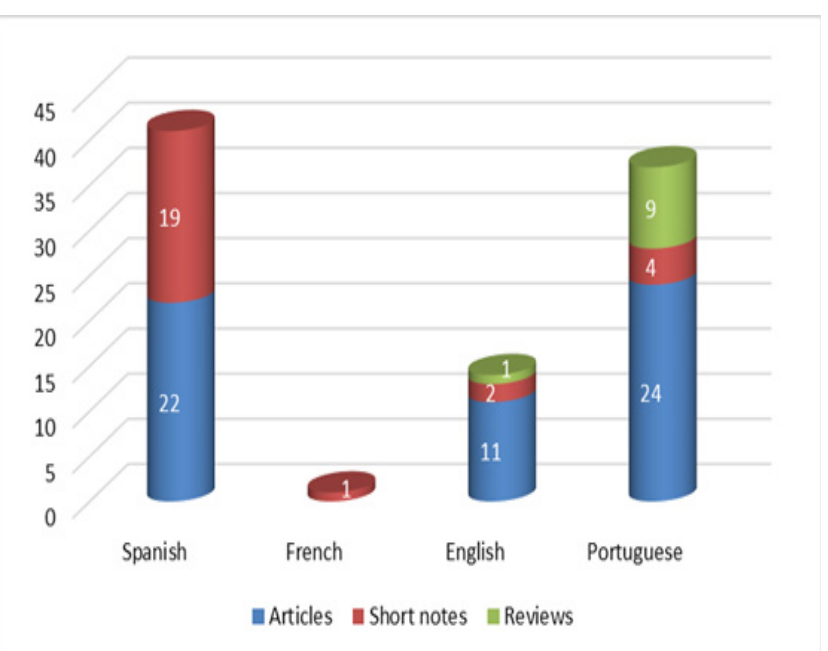

Figure 5. Language used in the manuscripts published during 2016 (Lenguaje empleado en los manuscritos publicados en 2016).

hed, is slightly progressively recovering to reach the numbers or even surpass the figures of 2014 for short notes (Nogales Baena et al., 2015; 2016).

Published manuscripts were written in four different languages (Figure 5), being the Portuguese the most frequent one $(42.25 \%)$. Contrasting the results from the previous year, the use of English increased until it reached the same level as Spanish was on (19 papers in each language, a $26.76 \%$ out of the total of paper published). These results confirm the advance of the use of English for the works in the journal.

According to the topics (Table II), published documents showed a distribution which was similar to the one showed by received documents. The most frequent dealt with "Feeding and Food" (27/93), followed by those which were about "Breeding and Genetics", and "Economy and management", showing rates of 20/93 and a 11/93, respectively.

From a different point of view, a classification of the documents was carried out taking into account the species or the group of species on which the research focused (Table III). It is important to remark the bovine species was specifically studied in 25 documents out of the total 93 number of works, as well as it was also the species with which the papers more frequently dealt as shown in the previous report (Nogales Baena et al., 2016). Other 15 documents were not specific. 17 focused on ovine and 11 did it on poultry, which were both the most studied species after cattle in the journal, respectively following the trend of previous years.

\section{EDITORIAL TIMING}

Each manuscript submitted to Archivos de Zootecnia is first reviewed by the members of the Editorial Board. Subsequently, the Editorial Board analyzes each submitted manuscript and decides which Section Editor it must be assigned to. Each Section Editor decides whether it must be reviewed (in which case at least two, and up to four reviewers, are assigned) or rejected. 
Table III. Species or group of species studied in manuscripts published during 2015 (Especies o grupos de especies estudiados en los manuscritos publicados durante 2015).

\begin{tabular}{|c|c|c|c|c|}
\hline & Articles & Short notes & Reviews & Total \\
\hline Bovine & 16 & 8 & 1 & 25 \\
\hline Ovine & 7 & 9 & 1 & 17 \\
\hline Caprine & 1 & 1 & 1 & 3 \\
\hline Porcine & 3 & 1 & 2 & 6 \\
\hline Equine & 2 & 1 & - & 3 \\
\hline Poultry & 8 & 3 & - & 11 \\
\hline Rabbit & 2 & - & - & 2 \\
\hline Beekeeping & 1 & - & - & 1 \\
\hline Aquaculture & 7 & 1 & - & 8 \\
\hline Alternative species & 1 & 1 & - & 2 \\
\hline Non-specific & 9 & 1 & 5 & 15 \\
\hline Total & 57 & 26 & 10 & 93 \\
\hline
\end{tabular}

The journal has added new Section Editors to the Editorial Board of Archivos de Zootecnia so as to balance the number of works assigned to each of them, because of the great number of manuscripts received.

Reviewers are chosen from a repertoire of 2091 renowned international experts. The mean editorial times during 2016 are reported in Table IV.

The average time between reception and acceptance was $240.90 \pm 127.52$ days, while the average time between acceptance and publication was $162.08 \pm 94.86$ days. The total days from reception to publication were $402.98 \pm 145.72$. Despite the increase in editorial times which were expected due to the major changes applied of the Journal's internal structure, this results cannot be considered to be totally negative, in contrast to the ones deduced from previous year's editorial reports (Gómez Castro et al., 2009;2010; 2011; 2012; 2013, Nogales Baena et al., 2015), as although there has been an increase in such editorial times which may be attributed to the recent changes taking place, the results obtained still follow the improving trend of last year's report, as they do not surpass the times obtained in 2014 (Nogales Baena et al., 2016). Still the results to be found in 2017 will clarify whether there has been a punctual setback or a real problem. In order to counteract this situation, measures are already being implemented in advance to prevent such problems from worsening.

The editorial timing has experimented a moderate increase when compared to the results obtained in 2015, what may be attributed to the changes in the Editorial Office and platform implemented. The existing time between the reception and acceptance of the papers has suffered an average increase of 27 days, which also increased to an average of 78 days in the case of the time between the acceptance and publishing of such papers. The total day count, considering both periods; i.e., the time between the reception of a work and its publishing experimented an increase of more than 104 days. The changes in publishing timing can be observed in Table IV and Figure 6. This data proves the implemented changes on the working methodology were effective as it had been predicted in advance.

\section{IMPACT FACTOR}

\section{Time (days)}

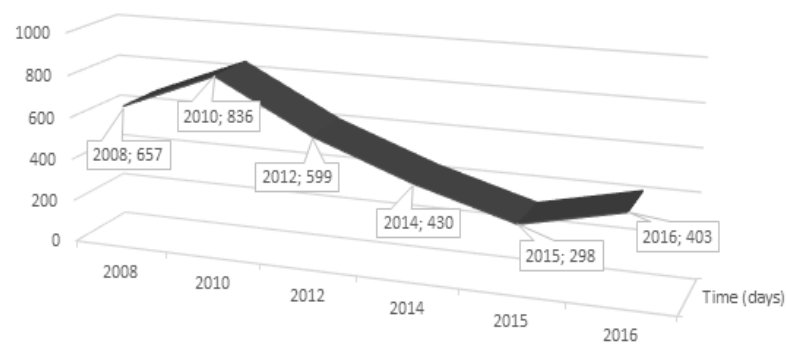

Figure 6. Editorial timing (reception-publishing) over the last years (Tiempos editoriales, recepción-publicación, durante los últimos años).

Table IV. Editorial timing during 2016; mean \pm standard deviation (Tiempos editoriales durante 2016; media \pm desviación típica).

\begin{tabular}{lccc}
\hline & Reception-Acceptation & Acceptation-Publication & Reception-Publication \\
\hline Articles & $243.95 \pm 123.21$ & $153.25 \pm 90.66$ & $397.19 \pm 148.82$ \\
Short notes & $220.04 \pm 112.96$ & $175.81 \pm 89.16$ & $395.85 \pm 145.40$ \\
Reviews & $277.80 \pm 183.05$ & $176.70 \pm 132.26$ & $454.50 \pm 131.17$ \\
\hline Total & $240.90 \pm 127.52$ & $162.08 \pm 94.86$ & $402.98 \pm 145.72$ \\
\hline
\end{tabular}



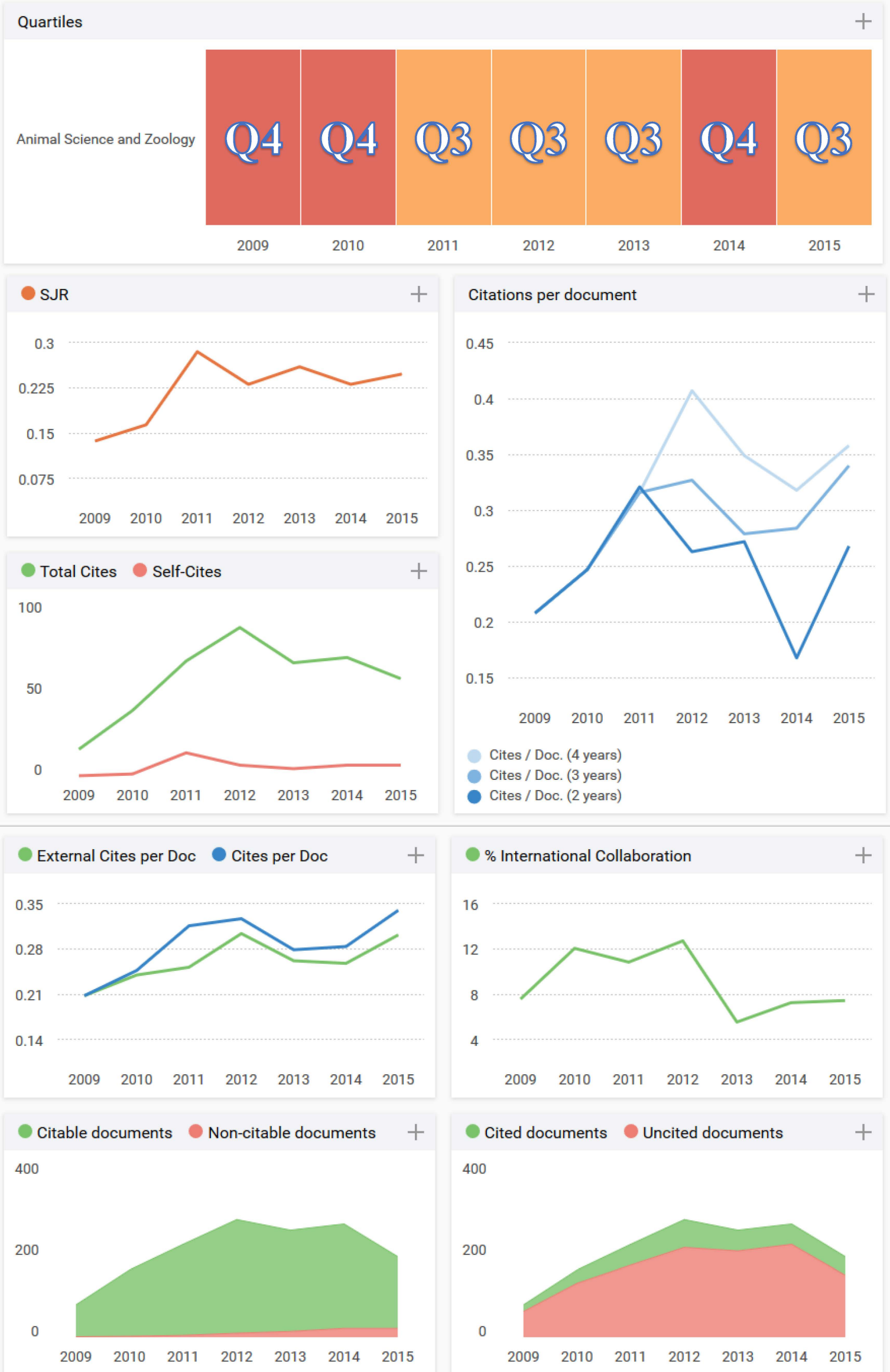

Cited documents Uncited documents $\quad+$ 400

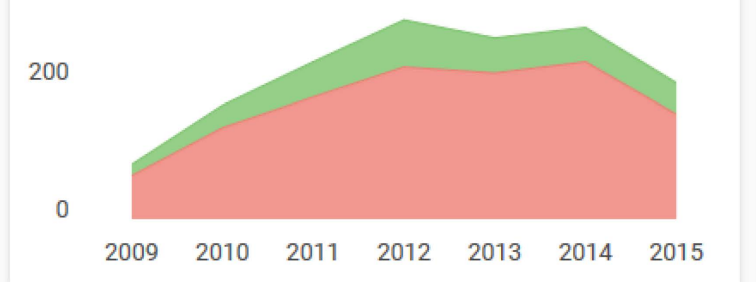

Figure 7. Impact factor evolution from 2009 until the previous editorial period 2016 (ScimagoLab, 2017) (Evolución del índice de impacto de 2009 hasta el pasado periodo editorial en 2016 (ScimagoLab, 2017)). 
Archivos de Zootecnia achieved an impact factor of 0.20 in the report of Research Gate (RG) in the period from 2015 to 2016, what means the journal is still located in the third quartile for the fifth year in a row and has doubled the value obtained for 2014.

One of the most remarkable achievements was the inclusion in the Web of Science of Thompson Reuters through the inclusion of the SCIELO citation index.

\section{NEW ORGANIGRAM AND OPEN JOURNAL SYSTEM IMPLEMENTATION}

The editorial board will be organized by section editors for each specific area. Each section editor will have responsibility only in a particular area. Section Editors will receive manuscripts for which they will be responsible from their assignment to their complete acceptance or rejection. No manuscript will be shared by more than one section editor; therefore each section editor will be fully responsible for the process of the manuscript assigned. More than one section editor may be assigned to an area depending on the number of manuscripts received concerning it. As it had been implemented already before the recent Editorial Board changes had been implemented, we will try to compensatedly load the section editors so as for them not to feel overloaded. This new responsibility of section editors does not allow us to maintain inoperative editors for long, therefore, if an editor came into the circumstances that prevented them from developing their work, they should contact the editorial office to temporarily or permanently be replaced by another, according to their own request. If an inactive section editor did not apply for temporary or permanent cessation, and did not meet the requirements of the editorial office, they will be discarded within a month.

Manuscripts will be specifically assigned to section editors by the director of the Journal in coordination with the chief editor. A section editor has 10 days to accept the management of the assigned manuscript or to reject it reasonable explaining their judgment in such a case (relationship with the authors, lack of specificity, among others). Upon the acceptance of the article, the section editor has 20 days to assign the pair of reviewers who they consider the most appropriate or to directly issue a judgement (notifying the authors with the reasons for it). This must delete any data concerning the authors' identity in order to ensure the blind double pair peer review process. If there is no reaction within 3 days, the assigned reviewer would necessarily have to be replaced by another reviewer following the same procedure as described above. Reviewers have 30 days to conduct the review. If they had not received any of these reviews, a reminder will be issued by the journal to the section editor in order for them to require it to the reviewer. The section editor can perform the assignment of additional reviewers at any time, always with the intention to speed up the process when the occasion demands it. Once the editors receive the two mandatory minimum revisions, they incorporate a comment on the recommendations of the reviewers and about their own opinion of the manuscript assigned into the system all together in a verdict that may be of acceptance, acceptance with light or deep modifications, or rejection. In the case of acceptance with modifications, the section editor through the director or the Editor-in-Chief will notify the authors for them to apply the required corrections within a maximum period of one month, leaving the door open for the application from the authors for a new one-month period. This extension, is only possible for two additional periods, therefore, at the third month without receiving the required corrections the manuscript will be rejected, demanding the authors a new referral of the same manuscript. If the manuscript has been finally accepted or rejected the responsibility for the process will change from the section editor to the editor-in-chief who will be charge of the notifications, print tests and linguistic review, among others.

\section{CONCLUSIONS}

The migration to the Open Journal System (OJS), one of the major challenges for the journal in the last years has been fullfilled during the 2016 period. Furthermore, several changes have been implemented in the editorial office. The editorial board consists of 32 section editors for the different specific areas. The Scientific Director and Editor-in-Chief are in charge of assigning the manuscript received through the OJS system. Despite all these changes, we think that the enormous challenges set forward have been approached successfully and we hope for them to consolidate during the next editorial period. On the other hand, the next great step to give involves the application of our journal to be evaluated by The Journal Citation Report index by Thompson Reuters $®$. The fisrt stage has consisted in applicating for Archivos de Zootecnia to be included in the Emerging Citation Reports which was completed in September, 2016.

\section{ACKNOWLEDGEMENTS}

Archivos de Zootecnia would like to express its most sincere gratitude to the Section Editors involved in the editorial process as well as the Reviewers without whose work our labour, otherwise would not be possible.

\section{BIBLIOGRAPHY}

Gómez Castro, A.G.; López de Bustamante, M.C.; Perea Muñoz, J. and Arcos Castejón, J. 2009. Editorial Report 2008. Arch Zootec, 58: 3-10. Gómez Castro, A.G.; López de Bustamante, M.C.; Perea Muñoz, J. and Arcos Castejón, J. 2010. Editorial Report 2009. Arch Zootec, 59: 3-10. Gómez Castro, A.G.; López de Bustamante, M.C.; Perea Muñoz, J. and Arcos Castejón, J. 2011 . Editorial Report 2010. Arch Zootec, 60: 3-10.

Gómez Castro, A.G.; López de Bustamante, M.C.; Perea Muñoz, J. and Arcos Castejón, J. 2012. Editorial Report 2011 . Arch Zootec, 61: 3-9. Gómez Castro, A.G.; López de Bustamante, M.C.; Perea Muñoz, J. and Arcos Castejón, J. 2013. Editorial Report 2012. Arch Zootec, 62: 3-7. Nogales Baena, S.; Arando Arbulu, A.; Delgado Bermejo, J.V., López de Bustamante, M.C. and Gómez Castro, A.G. 2015. Editorial Report 2014. Arch Zootec, 64: 1-4.

Nogales Baena. S.; Arando Arbulu, A.; Navas González, F.J.; Barona Hernández, L.; Delgado Bermejo, J.V.; López de Bustamante, M.C. and Gómez Castro, A.G. 2016. Editorial Report 2015. Arch Zootec, 65: 1-6. ScimagoLab 2017. SClmago Journal \& Country Rank. Inc. Accessed from http://scimagoir.com/journalsearch.php? $q=11700154375 \&$ tip $=$ sid (10/04/2017). 